\title{
Extensive weight loss can reduce immune age by altering
}

\section{IgG N-glycosylation}

Valentina L Greto, $\mathrm{PhD}^{1 *}$, Ana Cvetko, $\mathrm{MSc}^{2 *}$, Tamara Štambuk, $\mathrm{PhD}^{2,3 *}$, Niall J Dempster, $\mathrm{MD}^{4}$, Domagoj Kifer, $\mathrm{MSc}^{2}$, Helena Deriš, $\mathrm{MSc}^{3}$, Ana Cindrić, $\mathrm{MSc}^{3}$, Frano Vučković, $\mathrm{PhD}^{3}$, Mario Falchi, $\mathrm{PhD}^{5}$, Richard S Gillies, $\mathrm{MD}^{6}$, Jeremy W Tomlinson, $\mathrm{PhD}^{4}$, Olga Gornik, $\mathrm{PhD}^{2,3}$, Bruno Sgromo, $\mathrm{MD}^{6}$, Tim D Spector, $\mathrm{PhD}^{5}$, Cristina Menni, $\mathrm{PhD}^{5 *}$, Alessandra Geremia, $\mathrm{PhD}^{1 *}$, Carolina V Arancibia-Cárcamo, $\mathrm{PhD}^{1 *}$, Gordan Lauc, $\mathrm{PhD}^{2,3 *}$

${ }^{1}$ Translational Gastroenterology Unit and NIHR Oxford Biomedical Research Centre, Nuffield Department of Medicine, University of Oxford, United Kingdom

${ }^{2}$ Faculty of Pharmacy and Biochemistry, University of Zagreb, Zagreb, Croatia

${ }^{3}$ Genos Glycoscience Research Laboratory, Zagreb, Croatia

${ }^{4}$ Oxford Centre for Diabetes and NIHR Oxford Biomedical Research Centre, Endocrinology and Metabolism, Radcliffe Department of Medicine, University of Oxford, United Kingdom

${ }^{5}$ The Department of Twin Research, King's College London, St Thomas' Hospital, London, United Kingdom

${ }^{6}$ Department of Upper GI Surgery, Oxford University Hospitals, United Kingdom

*The authors equally contributed to this work

Running title: Weight loss improves aging and IgG N-glycosylation

Corresponding author:

Gordan Lauc

glauc@pharma.hr

Faculty of Pharmacy and Biochemistry, University of Zagreb

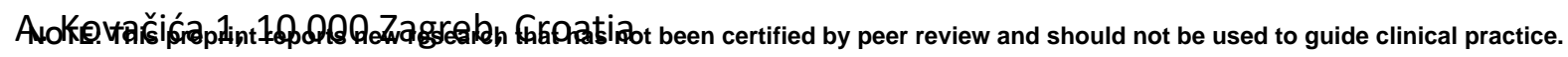


medRxiv preprint doi: https://doi.org/10.1101/2020.04.24.20077867; this version posted September 3, 2020. The copyright holder for this preprint (which was not certified by peer review) is the author/funder, who has granted medRxiv a license to display the preprint in It is made available under a CC-BY-NC-ND 4.0 International license.

\section{AUTHORS` DECLARATION OF INTEREST}

Tamara Štambuk Declaration of interest: Dr. Štambuk reports that she is an employee of Genos Glycoscience Research Laboratory which offers commercial service of glycomic analysis and has several patents in the field.

Helena Deriš Declaration of interest: Helena Deriš reports that she is an employee of Genos Glycoscience Research Laboratory which offers commercial service of glycomic analysis and has several patents in the field.

Ana Cindrić Declaration of interest: Ana Cindrić reports that she is an employee of Genos Glycoscience Research Laboratory which offers commercial service of glycomic analysis and has several patents in the field.

Frano Vučković Declaration of interest: Dr. Vučković reports that he is an employee of Genos Glycoscience Research Laboratory which offers commercial service of glycomic analysis and has several patents in the field.

Olga Gornik Declaration of interest: Dr. Gornik reports that she is an employee of Genos Glycoscience Research Laboratory which offers commercial service of glycomic analysis and has several patents in the field.

Alessandra Geremia Declaration of interest: Dr. Geremia reports grants from Wellcome Trust, grants from NIHR research capability fund, during the conduct of the study; other from UCB Pharma, outside the submitted work.

Gordan Lauc Declaration of interest: Dr. Lauc reports that he is founder and owner of Genos LTD Zagreb; In addition, Dr. Lauc has a multiple patents in the field of glycoscience pending or issued. 
medRxiv preprint doi: https://doi.org/10.1101/2020.04.24.20077867; this version posted September 3, 2020. The copyright holder for this preprint (which was not certified by peer review) is the author/funder, who has granted medRxiv a license to display the preprint in It is made available under a CC-BY-NC-ND 4.0 International license. 
medRxiv preprint doi: https://doi.org/10.1101/2020.04.24.20077867; this version posted September 3, 2020. The copyright holder for this preprint (which was not certified by peer review) is the author/funder, who has granted medRxiv a license to display the preprint in It is made available under a CC-BY-NC-ND 4.0 International license .

\section{ABSTRACT}

\section{Background}

49

Obesity is a major global health problem, and is associated with increased cardiometabolic morbidity and mortality. Protein glycosylation is a frequent postranslational modification, highly responsive to numerous pathophysiological conditions and ageing. The prospect of biological age reduction, by reverting glycosylation changes through metabolic intervention, opens many possibilities. We have investigated whether weight loss interventions affect inflammation- and ageing-associated IgG glycosylation changes, in a longitudinal cohort of bariatric surgery patients. To support potential findings, BMI-related glycosylation changes were monitored in a longitudinal twins cohort.

\section{Methods}

IgG N-glycans were chromatographically profiled in 37 obese patients, subjected to lowcalorie diet, followed by bariatric surgery, across multiple timepoints. Similarly, plasmaderived IgG N-glycan traits were longitudinally monitored in 1,680 participants from the TwinsUK cohort.

\section{Results}

Low-calorie diet induced a marked decrease in the levels of IgG N-glycans with bisecting GlcNAc, whose higher levels are usually associated with ageing and inflammatory conditions. Bariatric surgery resulted in extensive alterations of the IgG glycome that accompanied progressive weight loss during one-year follow-up. We observed a significant increase in digalactosylated and sialylated glycans, and a substantial decrease in agalactosylated and core fucosylated IgG glycans. In general, this IgG glycan profile is associated with a younger biological age and reflects an enhanced anti-inflammatory IgG potential. Loss of BMI over a 
medRxiv preprint doi: https://doi.org/10.1101/2020.04.24.20077867; this version posted September 3, 2020. The copyright holder for this preprint (which was not certified by peer review) is the author/funder, who has granted medRxiv a license to display the preprint in It is made available under a CC-BY-NC-ND 4.0 International license.

70

71

72

73

74

75

76

77

78

79

80

81

82

83

84

85

86

87

20 year period in the TwinsUK cohort validated a weight loss-associated agalactosylation

decrease and an increase in digalactosylation.

\section{Conclusions}

Altogether, these findings highlight that weight loss substantially affects IgG N-glycosylation, resulting in reduced biological and immune age.

\section{GRAPHICAL ABSTRACT}

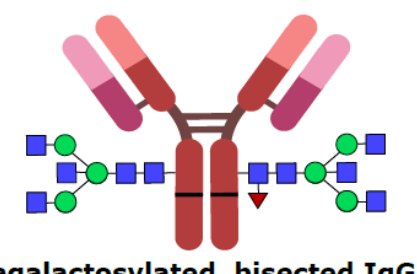

agalactosylated, bisected IgG

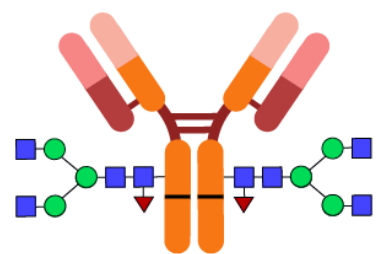

agalactosylated IgG

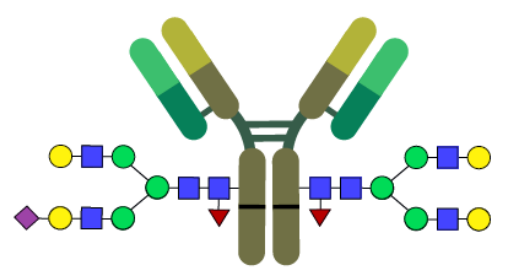

galactosylated and sialylated IgG

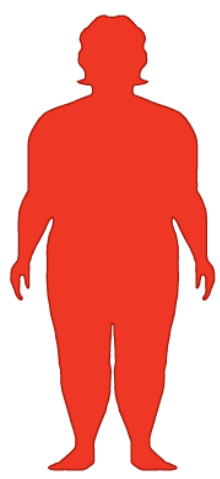

low-calorie diet
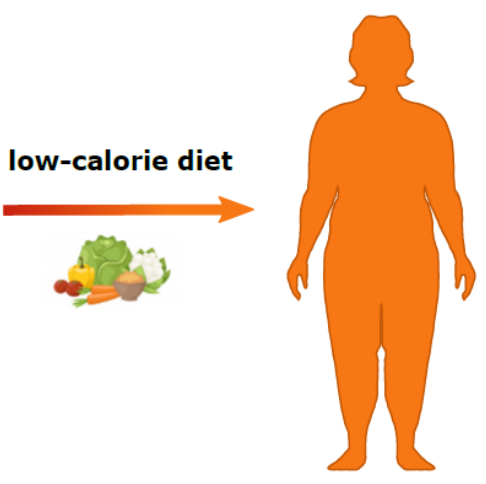

bariatric surgery
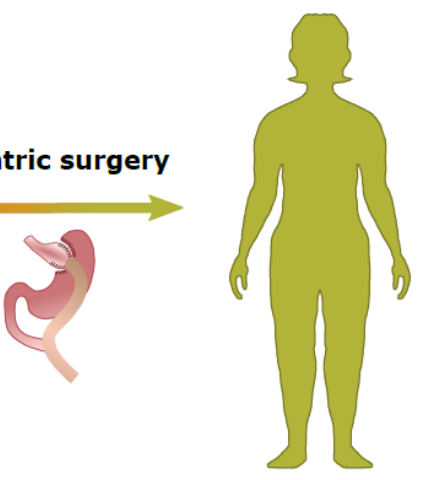

\section{HIGHLIGHTS}

- Obesity is associated to inflammation-related agalactosylated and bisected IgG glycoforms

- IgG galactosylation and sialylation increase after bariatric surgery-induced weight loss

- Progressive decrease of BMI is associated to increased IgG galactosylation, implying a reduction of biological age

\section{KEYWORDS}

$\mathrm{N}$-glycosylation; bariatric surgery; weight loss; immunoglobulin G; biological age 
medRxiv preprint doi: https://doi.org/10.1101/2020.04.24.20077867; this version posted September 3, 2020. The copyright holder for this preprint (which was not certified by peer review) is the author/funder, who has granted medRxiv a license to display the preprint in It is made available under a CC-BY-NC-ND 4.0 International license .

88

89

90 proposed to express the difference between chronological and IgG glycome ageing [11]. The

\section{INTRODUCTION}

The global prevalence of obesity has risen dramatically in the past decades, and it is now considered a pandemic [1]. According to the World Health Organization, over 650 million individuals are obese, accounting for $13 \%$ of the world's adult population. Obesity confers a risk for metabolic syndrome, contributing to type 2 diabetes and cardiovascular disease (CVD) development [2]. Metabolic syndrome is linked to a chronic systemic low-grade inflammation, which contributes to the aging of the immune system denoted as inflammaging $[3,4]$. Obesityrelated inflammaging results in impaired innate and adaptive immune function, and is characterized by high serum levels of IL-6, TNF- $\alpha$ and CRP [5]. Altered protein N-glycosylation is one of the hallmarks of inflammaging $[4,6]$. The human circulating $\mathrm{N}$-glycome represents the entire set of glycans that are covalently attached to plasma proteins through a nitrogen on an asparagine residue. N-glycans are essential for life and are involved in many physiological processes [7], including signal transduction, protein trafficking and folding, receptor regulation and cell adhesion. Glycosylation has a fundamental role in the innate and adaptive immune responses, accentuated by the fact that all five classes of immunoglobulins (Ig) bear N-glycans. In this regard, IgG is probably the most investigated glycoprotein, whose effector functions are controlled by its Fc-bound glycans [8].

Inter-individual differences in the pace of biological ageing is an intriguing concept which may contribute to why some people stay healthy until their late chronological age, while others age faster and have shorter life expectancy. Progressive age-related changes of IgG glycosylation have been extensively studied $[7,9,10]$ and the GlycanAge model has been age of the IgG glycome might be estimated through the levels of agalactosylated species, which increase with ageing and are associated with enhanced immune activation [12]. The 
medRxiv preprint doi: https://doi.org/10.1101/2020.04.24.20077867; this version posted September 3, 2020. The copyright holder for this preprint (which was not certified by peer review) is the author/funder, who has granted medRxiv a license to display the preprint in It is made available under a CC-BY-NC-ND 4.0 International license.

112 opposite applies for digalactosylated IgG glycoforms, which are usually related to a younger

113 age. Besides age-related changes, specific IgG glycosylation patterns have been already

114 associated with CVD risk score and subclinical atherosclerosis in two large independent UK

115 cohorts [13]. Moreover, a prospective follow-up of the EPIC-Potsdam cohort confirmed that

116 changes in plasma $\mathrm{N}$-glycome composition are predictive of future CVD events, with

117 comparable predictive power to the American Heart Association (AHA) score in men and even

118 better predictive power in women [14]. The link between a proinflammatory lgG N-glycome

119 and hypertension has also been extensively studied [15-17], and similar IgG glycosylation

120 patterns were associated with increased body mass index (BMI) and measures of central

121 adiposity $[18,19]$.

122 Studies in mouse models further corroborate the importance of differential IgG glycoforms in

123 CVD pathogenesis. It has been shown that hyposialylated IgG (corresponding to an old-like IgG

124 glycome) can induce obesity-related hypertension and insulin resistance in B-cell-deficient

125 mice, through activation of the endothelial FcyRIIB [20,21]. These findings indicate that the

126 IgG N-glycome could represent more than a biomarker of inflammation and aging, since

127 distinctive IgG glycoforms act as effector molecules in certain pathologies. Furthermore,

128 supplementation with $N$-acetylmannosamine (ManNAc), a precursor of sialic acid, protects

129 obese mice from hypertension and insulin resistance induction by reverting an IgG N-glycome

130 associated with old age into an IgG N-glycome associated with young age [21,22]. However,

131 studies exploring the possibilities of converting an old-like into a young-like lgG glycome by

132 metabolic intervention in humans are limited. Of note, only one small study indicated that

133 high-intensity interval training can rejuvenate the IgG N-glycome [23].

134 Bariatric surgery is very effective for the treatment of severe obesity [24]. The resulting

135 weight loss impacts energy balance and metabolism, contributing to the increased insulin 
medRxiv preprint doi: https://doi.org/10.1101/2020.04.24.20077867; this version posted September 3, 2020. The copyright holder for this preprint (which was not certified by peer review) is the author/funder, who has granted medRxiv a license to display the preprint in It is made available under a CC-BY-NC-ND 4.0 International license .

response, improved glycaemic control and reduction of total body fat, leading to decreased

137 CVD risk and mortality [25].

138 In this study we aimed to determine whether weight loss affects glycan markers related to 139 inflammation and ageing, in a longitudinally-monitored cohort of obese individuals 140 undergoing low-calorie diet and then bariatric surgical interventions. We also investigated 141 BMI-related glycosylation changes in the longitudinal TwinsUK cohort, the largest cohort of 142 adult twins with the most detailed clinical database in the world.

\section{METHODS}

\section{Study populations}

146 Bariatric cohort. The cohort included 37 participants, recruited at Oxford University Hospitals

147 to the Gastrointestinal Illnesses study (Ref: 16/YH/0247). All patients were characterised by 148 metabolic status and medical history. Bariatric patients were considered eligible in accordance 149 to National Institute for Health and Care Excellence (NICE) and local guidelines.

150 Patients with a history of alcoholism and/or ongoing anticoagulant treatment were excluded.

151 Patients were also excluded in case of pregnancy, active substance abuse or uncontrolled 152 psychiatric condition including eating disorders. Participants were sampled at baseline and 153 subjected to 3-week low calorie carbohydrate-restricted diet $(900 \mathrm{cal}$, maximum $100 \mathrm{~g}$ of 154 carbohydrates per day), followed by bariatric surgery. The sequential follow-up timepoints 155 included the day of the surgery (baseline), at $20 \%$ of weight loss after $6.54 \pm 3.4$ months (mean $156 \pm(\mathrm{IQ})$ and $12.47 \pm 6.55$ months post-op. Characteristics of the bariatric cohort are shown in 157 Table 1.

158 TwinsUK cohort. We have analysed a total of 6,032 plasma samples from 2,146 participants of 159 the TwinsUK study, collected at multiple timepoints over a 20 year-period [26]. These included 
medRxiv preprint doi: https://doi.org/10.1101/2020.04.24.20077867; this version posted September 3, 2020. The copyright holder for this preprint (which was not certified by peer review) is the author/funder, who has granted medRxiv a license to display the preprint in It is made available under a CC-BY-NC-ND 4.0 International license .

1601,865 individuals sampled at 3 timepoints, 156 individuals sampled at 2 timepoints and 125

161 individuals sampled only once. Following the plasma N-glycome analysis, glycan data 162 underwent quality control (see Statistical analysis section), which decreased the dataset to 1635,889 samples (measurements). Out of these 5,889 measurements, we have proceeded with 164 statistical analysis on a subset of 3,742 samples (measurements) which had information on BMI available. Description of the TwinsUK cohort is provided in Table 2.

\section{Ethical statement}

167 Ethical approval for the study was obtained by the National Research Ethics Committees of 168 the UK National Health Service (NHS) under the reference number 16/YH/0247. All individuals 169 participating in this study gave written informed consent. The TwinsUK study was approved 170 by NRES Committee London-Westminster, and all twins provided informed written consent.

\section{$171 \quad \mathrm{~N}$-glycome analysis}

\section{Isolation of IgG from human plasma}

173 IgG was isolated from plasma samples by affinity chromatography as described previously 174 [27]. In brief, IgG was isolated in a high-throughput manner, using 96-well protein G 175 monolithic plates (BIA Separations, Slovenia), starting from $100 \mu$ of plasma. Plasma was 176 diluted 7x with phosphate buffered saline (PBS; Merck, Germany) and applied to the protein $177 \mathrm{G}$ plate. IgG was eluted with $1 \mathrm{ml}$ of $0.1 \mathrm{M}$ formic acid (Merck, Germany) and immediately 178 neutralized with $1 \mathrm{M}$ ammonium bicarbonate (Acros Organics, USA).

\section{$179 \quad$-glycan release from IgG and total plasma proteins}

180 Isolated IgG samples were dried in a vacuum centrifuge. After drying, IgG was denatured with 181 the addition of $30 \mu \mathrm{l}$ of $1.33 \%$ SDS (w/v) (Invitrogen, USA) and by incubation at $65{ }^{\circ} \mathrm{C}$ for 10 182 min. Plasma samples $(10 \mu \mathrm{l})$ were denatured with the addition of $20 \mu \mathrm{l}$ of $2 \%(\mathrm{w} / \mathrm{v})$ SDS 183 (Invitrogen, USA) and by incubation at $65^{\circ} \mathrm{C}$ for $10 \mathrm{~min}$. From this point on, the procedure was 
medRxiv preprint doi: https://doi.org/10.1101/2020.04.24.20077867; this version posted September 3, 2020. The copyright holder for this preprint (which was not certified by peer review) is the author/funder, who has granted medRxiv a license to display the preprint in It is made available under a CC-BY-NC-ND 4.0 International license .

184 identical for both IgG and plasma samples. After denaturation, $10 \mu$ of $4 \%(v / v)$ Igepal-CA630

185 (Sigma Aldrich, USA) was added to the samples, and the mixture was shaken 15 min on a plate 186 shaker (GFL, Germany). N-glycans were released with the addition of $1.2 \mathrm{U}$ of PNGase F 187 (Promega, USA) and overnight incubation at $37^{\circ} \mathrm{C}$.

188 Fluorescent labelling and HILIC SPE clean-up of released N glycans

189 The released $\mathrm{N}$-glycans were labelled with 2-aminobenzamide (2-AB). The labelling mixture 190 consisted of 2-AB (19.2 mg/ml; Sigma Aldrich, USA) and 2-picoline borane ( $44.8 \mathrm{mg} / \mathrm{ml}$; Sigma 191 Aldrich, USA) in dimethyl sulfoxide (Sigma Aldrich, USA) and glacial acetic acid (Merck, 192 Germany) mixture (70:30 v/v). To each sample $25 \mu$ l of labelling mixture was added, followed 193 by $2 \mathrm{~h}$ incubation at $65^{\circ} \mathrm{C}$. Free label and reducing agent were removed from the samples 194 using hydrophilic interaction liquid chromatography solid-phase extraction (HILIC-SPE). After 195 incubation samples were brought to $96 \%$ of acetonitrile (ACN) by adding $700 \mu$ l of ACN (J.T. Baker, USA) and applied to each well of a $0.2 \mu \mathrm{m}$ GHP filter plate (Pall Corporation, USA).

197 Solvent was removed by application of vacuum using a vacuum manifold (Millipore 198 Corporation, USA). All wells were prewashed with 70\% ethanol (Sigma-Aldrich, St. Louis, MO, 199 USA) and water, followed by equilibration with 96\% ACN. Loaded samples were subsequently washed $5 \times$ with $96 \%$ ACN. N-glycans were eluted with water and stored at $-20^{\circ} \mathrm{C}$ until usage.

Hydrophilic interaction liquid chromatography of N-glycans

Fluorescently labelled $\mathrm{N}$-glycans were separated by hydrophilic interaction liquid chromatography (HILIC) on Acquity UPLC H-Class instrument (Waters, USA) consisting of a quaternary solvent manager, sample manager and a fluorescence detector, set with excitation and emission wavelengths of 250 and $428 \mathrm{~nm}$, respectively. The instrument was under the

206 control of Empower 3 software, build 3471 (Waters, Milford, USA). Labelled N-glycans were 
medRxiv preprint doi: https://doi.org/10.1101/2020.04.24.20077867; this version posted September 3, 2020. The copyright holder for this preprint (which was not certified by peer review) is the author/funder, who has granted medRxiv a license to display the preprint in It is made available under a CC-BY-NC-ND 4.0 International license .

208 formate, $\mathrm{pH} 4.4$, as solvent $\mathrm{A}$ and $\mathrm{ACN}$ as solvent $\mathrm{B}$. In the case of IgG N-glycans, separation

209 method used linear gradient of $75-62 \%$ acetonitrile at flow rate of $0.4 \mathrm{ml} / \mathrm{min}$ in a $27-\mathrm{min}$

210 analytical run. For plasma protein N-glycans separation method used linear gradient of 70-

$21153 \%$ acetonitrile at flow rate of $0.561 \mathrm{ml} / \mathrm{min}$ in a $25-\mathrm{min}$ analytical run. The system was

212 calibrated using an external standard of hydrolysed and 2-AB labelled glucose oligomers from

213 which the retention times for the individual glycans were converted to glucose units (GU).

214 Data processing was performed using an automatic processing method with a traditional

215 integration algorithm after which each chromatogram was manually corrected to maintain

216 the same intervals of integration for all the samples. The chromatograms were all separated

217 in the same manner into 24 peaks (GP1- GP24) for IgG N-glycans and 39 peaks (GP1-GP39)

218 for plasma protein N-glycans and are depicted in Supplementary Figure 1 and Supplementary

219 Figure 2, respectively. Detailed description of glycan structures corresponding to each glycan

220 peak is presented in Supplementary Table 1. Glycan peaks were analysed based on their

221 elution positions and measured in glucose units, then compared to the reference values in the

222 "GlycoStore" database (available at: https://glycostore.org/) for structure assignment. The

223 amount of glycans in each peak was expressed as a percentage of the total integrated area.

224 For IgG glycans, in addition to 24 directly measured glycan traits, 8 derived traits were

225 calculated (Supplementary Table 2). In the case of TwinsUK cohort, IgG N-glycan traits were

226 calculated from plasma protein glycan profiles, based on known elution positions of

227 predominat IgG glycan structures (Supplementary Table 3). In general, derived glycan traits

228 average particular glycosylation features, such as galactosylation, fucosylation, bisecting

229 GlcNAc, and sialylation. 
medRxiv preprint doi: https://doi.org/10.1101/2020.04.24.20077867; this version posted September 3, 2020. The copyright holder for this preprint (which was not certified by peer review) is the author/funder, who has granted medRxiv a license to display the preprint in It is made available under a CC-BY-NC-ND 4.0 International license.

\section{Statistical analysis}

233 Bariatric cohort. In order to remove experimental variation from the measurements, 234 normalization and batch correction were performed on the UPLC glycan data. To make 235 measurements across samples comparable, normalization by total area was performed. Prior 236 to batch correction, normalized glycan measurements were log-transformed due to right237 skewness of their distributions and the multiplicative nature of batch effects. Batch correction 238 was performed on log-transformed measurements using the ComBat method (R package sva 239 [28], where the technical source of variation (which sample was analysed on which plate) was modelled as batch covariate. To correct measurements for experimental noise, estimated batch effects were subtracted from log-transformed measurements.

242 Longitudinal analysis of patient samples through their observation period was performed by

243 implementing a linear mixed effects model, where time was modelled as fixed effect, while 244 the individual ID was modelled as random effect. Prior to the analyses, glycan variables were 245 all transformed to standard Normal distribution by inverse transformation of ranks to 246 Normality (R package "GenABEL", function rntransform). Using rank transformed variables 247 makes estimated effects of different glycans comparable, as these will have the same 248 standardized variance. False discovery rate (FDR) was controlled by the Benjamini-Hochberg 249 procedure at the specified level of 0.05 . Data was analysed and visualized using $\mathrm{R}$ 250 programming language (version 3.5.2)[29].

251 TwinsUK cohort. Normalization of peak intensities to the total chromatogram area was 252 performed for each measured sample separately. Calculated proportions were then batch 253 corrected using ComBat method (R package sva)[28]. After the batch correction the first 11 254 peaks, which predominantly originate from IgG [30], were used to calculate 6 derived glycan 255 traits - agalactosylation (G0), monogalactosylation (G1), digalactosylation (G2), bisecting 
medRxiv preprint doi: https://doi.org/10.1101/2020.04.24.20077867; this version posted September 3, 2020. The copyright holder for this preprint (which was not certified by peer review) is the author/funder, who has granted medRxiv a license to display the preprint in It is made available under a CC-BY-NC-ND 4.0 International license .

256 GlcNAc (B), core fucosylation (CF) and high mannose structures (HM). Mixed models were

257 fitted to estimate the effect of BMI change on IgG N-glycome (R package Ime4)[31]. Directly

258 measured or derived glycan trait was used as a dependent variable in the mixed model. To

259 differentiate between BMI change and the absolute BMI value, the variable was separated to

$260 \mathrm{BMI}_{\text {baseline }}$ and $\mathrm{BMI}_{\text {difference }}$ (calculated according to the following equation: $B M I_{\text {difference }}=$

$\left.261 B M I_{\text {follow up age }}-B M I_{\text {baseline age }}\right)$, and both were used in the model as a fixed effect. Since

262 IgG N-glycome is affected by aging, age was included both as a fixed effect and a random

263 slope. Finally, to meet the independency criteria, family ID and individual ID (nested within

264 family) were included in the model as a random intercept. Due to multiple model fitting (for

26511 directly measured and 6 derived glycan traits) false discovery rate was controlled using

266 Benjamini-Hochberg method. All statistical analyses were performed using R programming

267 language (version 3.6.3)[29].

\section{RESULTS}

\section{Impact of pre-surgical low-calorie diet on IgG glycosylation}

271 We chromatographically profiled the IgG N-glycome in a cohort of bariatric surgery-candidate

272 patients before and after the pre-operative diet. By employing a linear mixed model, we

273 observed significant change in only one out of eight examined IgG derived glycan traits.

274 Namely, the levels of bisecting GIcNAc (B) were substantially decreased after the low-calorie

275 diet intervention (Table 3), indicating a decreased proinflammatory potential of the circulating

276 IgG. The other IgG glycosylation features did not exhibit significant alterations, possibly due

277 to rather short follow-up period ( 3 weeks) and limited number of participants $(n=8)($ Table

278 3).Graphical representation of the longitudinal alterations in IgG N-glycome after low-calorie

279 diet are depicted in Supplementary Figure 3. 
medRxiv preprint doi: https://doi.org/10.1101/2020.04.24.20077867; this version posted September 3, 2020. The copyright holder for this preprint (which was not certified by peer review) is the author/funder, who has granted medRxiv a license to display the preprint in It is made available under a CC-BY-NC-ND 4.0 International license.

282 Using the same chromatographic approach, we analysed samples from patients who 283 underwent bariatric surgery. The plasma samples were collected on the day of surgery (month 284 0), approximately 6 months post-surgery and 12 months post-surgery. IgG N-glycans were 285 profiled in each of these timepoints, and the obtained values were used for derived glycan 286 traits calculations. Statistical analysis revealed extensive changes in IgG N-glycome following 287 the bariatric procedure. Namely, four out of eight tested derived traits showed marked 288 changes: core fucosylated (CF) and agalactosylated (G0) glycans decreased, while 289 digalactosylated (G2) and monosialylated (S1) glycans increased after the surgery (Table 4). 290 The IgG glycans whose abundances were increased after bariatric surgery are major 291 components of a young IgG glycome, as they are typically associated with a younger age. The 292 opposite applies to agalactosylated structures, which are usual denominators of an old-like 293 IgG glycome profile. We also examined the correlation of patients' clinical data with IgG N294 glycome features using multivariate analysis, but found no statistically significant associations 295 (Supplementary Table 4). Finally, the type of bariatric surgery (either sleeve gastrectomy or 296 Roux-en-Y gastric bypass) did not affect IgG glycome composition. Graphical representations 297 of the longitudinal alterations in IgG glycosylation features are depicted in Figure 1. 
medRxiv preprint doi: https://doi.org/10.1101/2020.04.24.20077867; this version posted September 3, 2020. The copyright holder for this preprint (which was not certified by peer review) is the author/funder, who has granted medRxiv a license to display the preprint in It is made available under a CC-BY-NC-ND 4.0 International license.
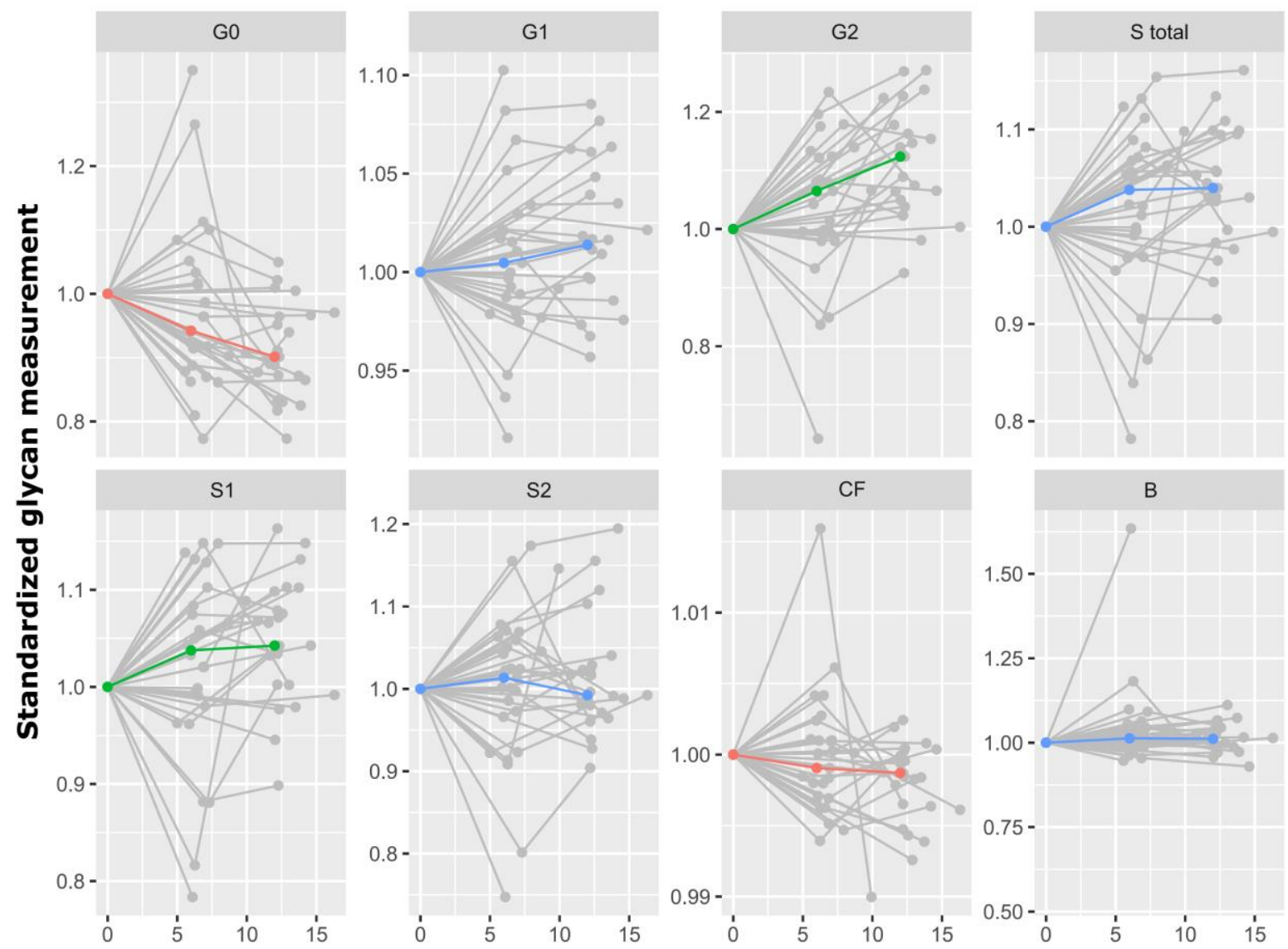

Time (months)

Figure 1 Bariatric surgery-related alterations in IgG N-glycome over time (months). Red line -

significant decrease; green line - significant increase; blue line - non-significant change.

\section{Weight loss induces a shift towards young-like IgG N-glycome}

Using the same chromatographic approach, we profiled the plasma protein N-glycome from

1,680 TwinsUK study participants sampled at several timepoints over a 20-year-period. This

served as a replication of the findings from the bariatric cohort, whose participants exhibited

the reversal from old- to young-likelgG N-glycome due to weight loss. Due to the fact that for

TwinsUK cohort plasma glycome was profiled, we calculated derived traits and performed

statistical analysis based only on the first 11 plasma glycan peaks, corresponding to the glycans

predominantly originating from IgG [30]. We examined IgG glycome alterations associated

with changes in BMI using a mixed model on a subset of 3,742 samples. Out of six examined 
medRxiv preprint doi: https://doi.org/10.1101/2020.04.24.20077867; this version posted September 3, 2020. The copyright holder for this preprint (which was not certified by peer review) is the author/funder, who has granted medRxiv a license to display the preprint in It is made available under a CC-BY-NC-ND 4.0 International license .

311 changes - agalactosylation (G0), digalactosylation (G2) and incidence of high mannose

312 structures (HM) (Table 5). Namely, the abundance of digalactosylated (G2) glycans increased

313 with the BMI decrease, while the abundance of agalactosylated (G0) and high mannose

314 glycans (HM) decreased with the weight loss, estimated by the BMI drop. These findings are

315 in line with the results observed in the bariatric surgery cohort. Graphical representation of

316 the longitudinal BMI-dependent alterations of IgG glycosylation are depicted at Figure 2.

317
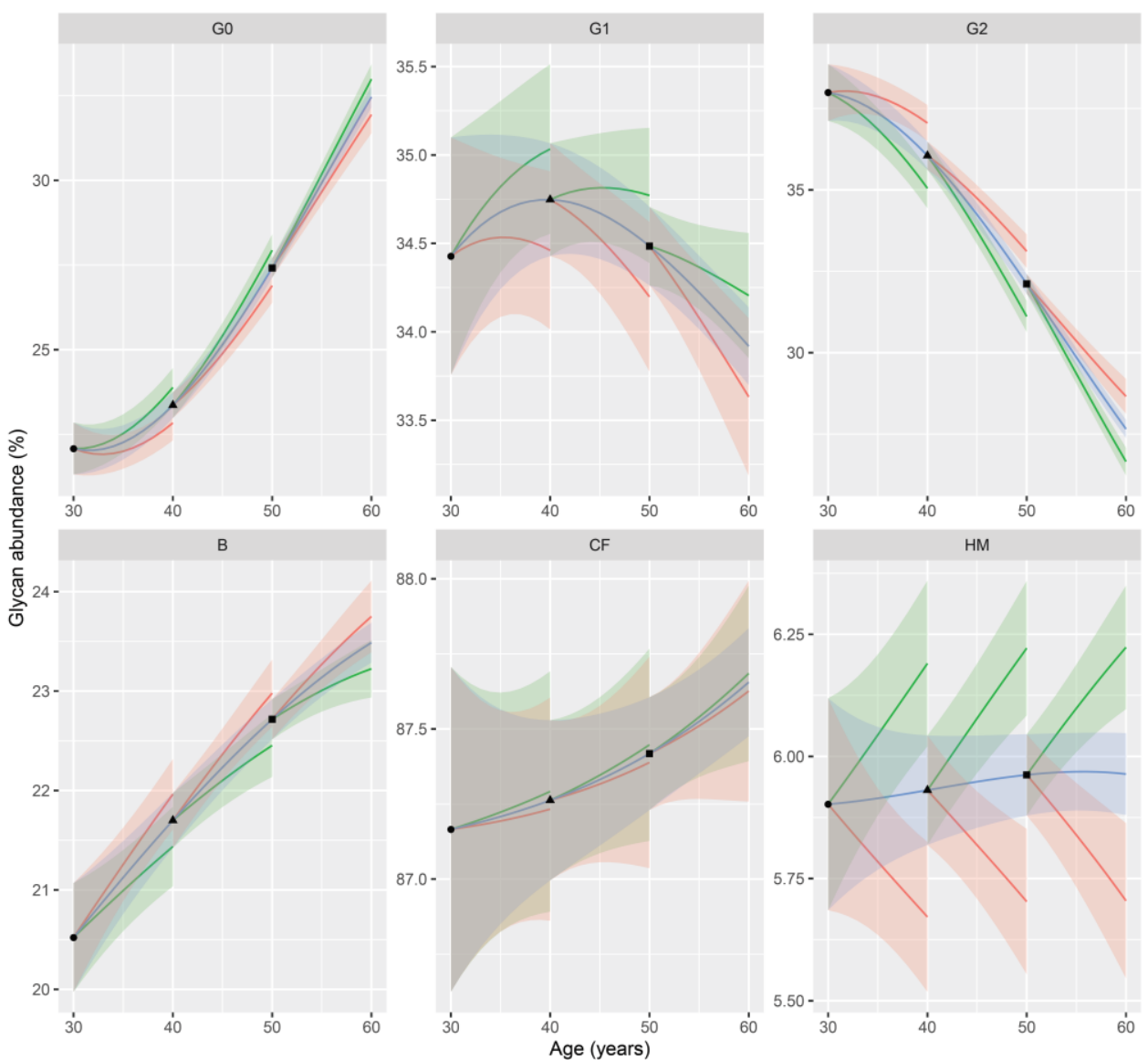

point (years)

- 30

40

- 50

\section{Figure 2 BMI-associated alterations in IgG N-glycosylation across multiple timepoints. Changes in IgG}

derived traits are presented with lineplots of hypothetical ageing of TwinsUK participants (all women).

Black dot represents a starting point of a 30-year-old woman, black triangle of a 40 -year-old woman and black square of a 50-year-old woman. All of these women have a baseline BMI of $25 \mathrm{~kg} \mathrm{~m}^{-2}$. Blue lines represent age-related IgG glycosylation changes attributed to stabile BMI. Green lines represent age-related IgG glycosylation changes attributed to increasing BMI $0.5 \mathrm{~kg} \mathrm{~m}^{-2}$ per year, through a period of 10 years). Red lines represent age-related IgG glycosylation changes attributed to decreasing 
medRxiv preprint doi: https://doi.org/10.1101/2020.04.24.20077867; this version posted September 3, 2020. The copyright holder for this preprint (which was not certified by peer review) is the author/funder, who has granted medRxiv a license to display the preprint in It is made available under a CC-BY-NC-ND 4.0 International license .

$325 \mathrm{BMI}\left(0.5 \mathrm{~kg} \mathrm{~m}^{-2}\right.$ per year, through a period of 10 years). Highlighted areas represent $95 \%$ confidence 326 intervals. The effect of age on IgG glycosylation is represented with the curve slope, while the effect 327 of BMI change is represented with the distance of green/red line from the blue line.

328

\section{DISCUSSION}

330 In this study, we have observed extensive changes in the IgG N-glycome associated with

331 weight loss following a low-calorie diet, bariatric surgery, or a decrease of BMI throughout 332 time. To the best of our knowledge, this is the first study to investigate IgG N-glycome 333 alterations in patients who underwent a low-calorie diet followed by bariatric surgery.

334 Prior to bariatric surgery, patients were subjected to a 3-week low-calorie diet which induced 335 a single significant change to the IgG N-glycome. Specifically, the levels of bisecting GlcNAc 336 were found to be reduced after the dieting period. In general, higher levels of bisecting GlcNAc 337 are associated with enhanced affinity for FcyRs and, consequently, with enhanced antibody338 dependent cellular cytotoxicity (ADCC) and other effector functions of the immune cells [9]. 339 Hence, the reduction of bisecting GIcNAc levels on IgG decreases IgG inflammatory potential. 340 Furthermore, several studies have reported a sex-independent increase in the levels of 341 bisecting GIcNAc with age $[32,33]$, suggesting that this diet-related decrease of its levels also 342 contributes to the reduction of the biological age. Lastly, increased abundance of bisecting 343 GlcNAc on IgG has been previously associated with type 2 diabetes [34] and with higher 344 cardiovascular risk [13], implying that dieting improves individual's cardiometabolic health 345 through altered IgG glycosylation as well. As for the other examined IgG glycosylation traits, 346 no significant changes were found to be associated with a low-calorie diet, probably due to 347 the relatively short follow-up period (three weeks), which matches IgG serum half-life. 
medRxiv preprint doi: https://doi.org/10.1101/2020.04.24.20077867; this version posted September 3, 2020. The copyright holder for this preprint (which was not certified by peer review) is the author/funder, who has granted medRxiv a license to display the preprint in It is made available under a CC-BY-NC-ND 4.0 International license .

348 Moreover, only 8 participants were subjected to the low-calorie diet intervention, hence,

349 further analysis on a larger sample size might reveal additional relevant changes.

350 We have also analysed IgG N-glycome from individuals who underwent bariatric surgery, in a

351 longitudinal manner. We observed several significant changes in IgG N-glycome, such as a

352 marked decrease in agalactosylated (G0) IgG. Elevated levels of G0 IgG glycoforms are

353 typically associated with aging, pro-inflammatory IgG glycan profile and various inflammatory

354 diseases [9]. On the other hand, the levels of digalactosylated (G2) glycans increased after

355 bariatric surgery and at sequential timepoints, in accordance with a reduced inflammatory

356 potential of the circulating IgG. The increased levels of IgG galactosylation were previously

357 associated with a younger biological age and are considered, in a way, as a measure of an

358 individual's well-being $[9,12]$. Converesely, IgG galactosylation levels substantially decrease

359 with ageing and during inflammation $[9,11]$. Our results demonstrate that weight loss,

360 resulting from bariatric surgery, can initiate the reversal from an old-like to a young-like IgG

$361 \mathrm{~N}$-glycome, potentially reversing the clock for the immune/biological age. Furthermore,

362 bariatric surgery also resulted in significant $\lg G$ glycome alteration inducing a decrease in core

363 fucosylation. The vast majority of circulating IgG molecules bears core fucose (approximately

364 95\%), which profoundly decreases IgG binding affinity to FcyRIIIA receptor and sequential

365 ADCC [35]. ADCC is largely mediated by natural killer cells that can lyse target cells and fight

366 viral infections. This would suggest that an extensive weight loss ameliorates immune

367 responses against pathogens, by altering IgG glycosylation and modulating its effector

368 functions. Lastly, bariatric surgery-related weight loss led to an increase in IgG sialylation,

369 which is the main modulator of the IgG anti-inflammatory actions [36]. In addition to its anti-

370 inflammatory actions, the level of IgG sialylation has been implicated in the pathogenesis of

371 obesity-induced insulin resistance and hypertension, as already mentioned [20,21]. Inhibitory 
medRxiv preprint doi: https://doi.org/10.1101/2020.04.24.20077867; this version posted September 3, 2020. The copyright holder for this preprint (which was not certified by peer review) is the author/funder, who has granted medRxiv a license to display the preprint in It is made available under a CC-BY-NC-ND 4.0 International license .

372 IgG receptor FcyRIIB was found to be expressed in the microvascular endothelium. Moreover,

373 it was shown that hyposialylated IgG acts as its operating ligand, leading to the induction of

374 obesity-related insulin resistance and hypertension. On the other hand, the sialylated

375 glycoform is not activating the signalling pathways responsible for the insulin resistance and

376 hypertension development, but is rather preserving insulin sensitivity and normal vasomotor

377 tone, even in obese mice. Interestingly, the same group made another significant discovery -

378 promotion of IgG sialylation breaks the link between obesity and hypertension/insulin

379 resistance [21,22]. Namely, supplementation with the sialic acid precursor restored IgG

380 sialylation, highlighting a potential approach to improve both metabolic and cardiovascular

381 health in humans, with a single intervention. Our data suggest that a similar effect might be

382 achieved by weight loss interventions, through restoring of IgG sialylation levels

383 In order to confirm the effects of weight loss on the biological immune age, we investigated

384 how a decreasing $\mathrm{BMI}$ affects the IgG N-glycome during a 20-year-period. We observed the

385 prominent inverse changes of agalactosylated (G0) and digalactosylated (G2) IgG glycans.

386 Namely, agalactosylated IgG glycans significantly decreased, while digalactosylated ones

387 substantially increased as the BMI decreased. These observations corroborated our findings

388 from the bariatric patients, confirming that the body weight reduction reverses IgG glycome

389 from old-like to young-like, implying at the same time a likely reduction in the biological and

390 immune age. Nonetheless, TwinsUK participants have not experienced such an extensive

391 weight loss, which potentially influenced the replication of other significant glycan changes

392 from the bariatric cohort; second - herein, the weight loss was approximated by BMI

393 decrease, which is usually a legitimate assumption, however, it does not have to apply to all

394 cases; and third -we profiled plasma glycome, while the IgG glycan traits were approximated

395 and the information on IgG sialylation was confounded by other plasma glycoproteins. Ideally, 
medRxiv preprint doi: https://doi.org/10.1101/2020.04.24.20077867; this version posted September 3, 2020. The copyright holder for this preprint (which was not certified by peer review) is the author/funder, who has granted medRxiv a license to display the preprint in It is made available under a CC-BY-NC-ND 4.0 International license .

396 these issues could be circumvented in the future studies whose experimental design would

397 allow the simultaneous, multi-centre follow-up of larger groups of patients.

398 Intense physical exercise can also shift IgG N-glycome towards a young-like profile by 399 increasing IgG galactosylation [23]. Although another study reported that prolonged intensive 400 exercise can have the opposite effect and promote pro-inflammatory changes of IgG N401 glycome [37], its findings are not surprising since it recruited healthy, normal-weight female 402 participants, subjected to the intense energy deprivation and exercise levels, to induce 403 substantial fat loss in a rather short time period. The authors also highlighted that starting 404 weight and the way in which weight loss is achieved could be crucial for the final effect on the 405 immune system [37]. Therefore, it seems that exercise overall has a positive impact on the 406 immune system and biological clock, but its intensity and duration should be personalized in 407 order to achieve the optimal results.

408 To summarize, our results indicate that both dieting and bariatric surgery have an impact on 409 inflammation and biological aging by altering IgG N-glycan patterns. All of the observed 410 weight-loss-associated alterations in IgG glycosylation are suggesting a decreased

411 inflammatory potential of the circulating IgG and a reduction of biological age. Hence, 412 improving metabolic and endocrine health through weight loss consequently also contributes 413 to the preservation of a healthy immune system.

\section{ACKNOWLEDGMENTS}

416 This research was funded by the National Institute for Health Research (NIHR) Oxford 417 Biomedical Research Centre (BRC). The views expressed are those of the author(s) and not 418 necessarily those of the NHS, the NIHR or the Department of Health. The authors thank Rachel 
medRxiv preprint doi: https://doi.org/10.1101/2020.04.24.20077867; this version posted September 3, 2020. The copyright holder for this preprint (which was not certified by peer review) is the author/funder, who has granted medRxiv a license to display the preprint in It is made available under a CC-BY-NC-ND 4.0 International license.

419 Franklin, Michelle Haylock, James Chivenga, Roxanne Williams and the BRC Oxford GI Biobank

420 for sample collection. The authors thank all the patients who took part in this study.

421

422 AUTHORS`CONTRIBUTION

423 Cristina Menni, Alessandra Geremia, Carolina V Arancibia-Cárcamo and Gordan Lauc:

424 Conceptualization, Supervision, Project administration, Funding acquisition. Valentina L

425 Greto, Ana Cvetko, Tamara Štambuk, Niall J Dempster, Helena Deriš, Ana Cindrić, Mario Falchi,

426 Cristina Menni: Investigation. Domagoj Kifer, Frano Vučković: Methodology, Software, Formal

427 analysis. Valentina L Greto, Ana Cvetko, Tamara Štambuk, Niall J Dempster, Domagoj Kifer,

428 Frano Vučković, Mario Falchi, Jeremy W Tomlinson, Olga Gornik, Tim Spector, Cristina Menni,

429 Alessandra Geremia, Carolina V Arancibia-Cárcamo, Gordan Lauc: Data curation and

430 visualization: Valentina L Greto, Ana Cvetko, Tamara Štambuk, Niall J Dempster, Domagoj

431 Kifer, Frano Vučković, Gordan Lauc: Writing-original draft. Valentina L Greto, Ana Cvetko,

432 Tamara Štambuk, Niall J Dempster, Domagoj Kifer, Helena Deriš, Ana Cindrić, Frano Vučković,

433 Mario Falchi, Richard S Gillies, Jeremy W Tomlinson, Olga Gornik, Bruno Sgromo, MD6, Tim D

434 Spector, Cristina Menni, Alessandra Geremia, Carolina V Arancibia-Cárcamo, Gordan Lauc:

435 Review \& Editing. 
medRxiv preprint doi: https://doi.org/10.1101/2020.04.24.20077867; this version posted September 3, 2020. The copyright holder for this preprint (which was not certified by peer review) is the author/funder, who has granted medRxiv a license to display the preprint in It is made available under a CC-BY-NC-ND 4.0 International license .

\section{REFERENCES}

[1] Obesity and overweight https://www.who.int/news-room/fact-sheets/detail/obesityand-overweight (accessed April 16, 2020).

[2] Han TS, Lean ME. A clinical perspective of obesity, metabolic syndrome and cardiovascular disease. JRSM Cardiovasc Dis 2016;5:2048004016633371. https://doi.org/10.1177/2048004016633371.

[3] Alpert A, Pickman Y, Leipold M, Rosenberg-Hasson Y, Ji X, Gaujoux R, et al. A clinically meaningful metric of immune age derived from high-dimensional longitudinal monitoring. Nat Med 2019;25:487-95. https://doi.org/10.1038/s41591-019-0381-y.

[4] Franceschi C, Garagnani P, Parini P, Giuliani C, Santoro A. Inflammaging: a new immune-metabolic viewpoint for age-related diseases. Nature Reviews Endocrinology 2018;14:576-90. https://doi.org/10.1038/s41574-018-0059-4.

[5] Touch S, Clément K, André S. T Cell Populations and Functions Are Altered in Human Obesity and Type 2 Diabetes. Curr Diab Rep 2017;17:81. https://doi.org/10.1007/s11892-017-0900-5.

[6] Lauc G, Sinclair D. Biomarkers of biological age as predictors of COVID-19 disease severity. Aging 2020. https://doi.org/10.18632/aging.103052.

[7] Lauc G, Pezer M, Rudan I, Campbell H. Mechanisms of disease: The human N-glycome. Biochimica et Biophysica Acta - General Subjects 2016;1860:1574-82. https://doi.org/10.1016/j.bbagen.2015.10.016.

[8] Gornik O, Pavić T, Lauc G. Alternative glycosylation modulates function of IgG and other proteins - implications on evolution and disease. Biochim Biophys Acta 2012;1820:1318-26. https://doi.org/10.1016/j.bbagen.2011.12.004.

[9] Gudelj I, Lauc G, Pezer M. Immunoglobulin G glycosylation in aging and diseases. Cellular Immunology 2018. https://doi.org/10.1016/j.cellimm.2018.07.009.

[10] Dall'Olio F. Glycobiology of aging. Subcellular Biochemistry, 2018. https://doi.org/10.1007/978-981-13-2835-0_17.

[11] Krištić J, Vučković F, Menni C, Klarić L, Keser T, Beceheli I, et al. Glycans Are a Novel Biomarker of Chronological and Biological Ages. The Journals of Gerontology: Series A 2014;69:779-89. https://doi.org/10.1093/gerona/glt190.

[12] Štambuk J, Nakić N, Vučković F, Pučić-Baković M, Razdorov G, Trbojević-Akmačić I, et al. Global variability of the human IgG glycome. Biochemistry; 2019. https://doi.org/10.1101/535237.

[13] Menni C, Gudelj I, MacDonald-Dunlop E, Mangino M, Zierer J, Bešić E, et al. Glycosylation Profile of Immunoglobulin G Is Cross-Sectionally Associated with Cardiovascular Disease Risk Score and Subclinical Atherosclerosis in Two Independent Cohorts. Circulation Research 2018;122:1555-64. https://doi.org/10.1161/CIRCRESAHA.117.312174.

[14] Wittenbecher C, Štambuk T, Kuxhaus O, Rudman N, Vučković F, Štambuk J, et al. Plasma $\mathrm{N}$-Glycans as Emerging Biomarkers of Cardiometabolic Risk: A Prospective Investigation in the EPIC-Potsdam Cohort Study. Diabetes Care 2020;43:661-8. https://doi.org/10.2337/dc19-1507.

[15] Gao Q, Dolikun M, Stambuk J, Wang H, Zhao F, Yiliham N, et al. Immunoglobulin G NGlycans as Potential Postgenomic Biomarkers for Hypertension in the Kazakh Population. Omics 2017;21:380-9. https://doi.org/10.1089/omi.2017.0044.

[16] Liu J, Dolikun M, Štambuk J, Trbojević-Akmačić I, Zhang J, Wang H, et al. The association between subclass-specific IgG Fc N-glycosylation profiles and hypertension in the 
medRxiv preprint doi: https://doi.org/10.1101/2020.04.24.20077867; this version posted September 3, 2020. The copyright holder for this preprint (which was not certified by peer review) is the author/funder, who has granted medRxiv a license to display the preprint in It is made available under a CC-BY-NC-ND 4.0 International license.

Uygur, Kazak, Kirgiz, and Tajik populations. J Hum Hypertens 2018;32:555-63. https://doi.org/10.1038/s41371-018-0071-0.

[17] Wang Y, Klarić L, Yu X, Thaqi K, Dong J, Novokmet M, et al. The Association Between Glycosylation of Immunoglobulin $\mathrm{G}$ and Hypertension: A Multiple Ethnic Cross-Sectional Study. Medicine 2016;95:e3379. https://doi.org/10.1097/MD.0000000000003379.

[18] Nikolac Perkovic M, Pucic Bakovic M, Kristic J, Novokmet M, Huffman JE, Vitart V, et al. The association between galactosylation of immunoglobulin $\mathrm{G}$ and body mass index. Progress in Neuro-Psychopharmacology and Biological Psychiatry 2014;48:20-5. https://doi.org/10.1016/j.pnpbp.2013.08.014.

[19] Russell AC, Kepka A, Trbojević-Akmačić I, Ugrina I, Song M, Hui J, et al. Increased central adiposity is associated with pro-inflammatory immunoglobulin $\mathrm{G} \mathrm{N}$-glycans. Immunobiology 2019;224:110-5. https://doi.org/10.1016/j.imbio.2018.10.002.

[20] Sundgren NC, Vongpatanasin W, Boggan BMD, Tanigaki K, Yuhanna IS, Chambliss KL, et al. IgG receptor FcyRIIB plays a key role in obesity-induced hypertension. Hypertension 2015;65:456-62. https://doi.org/10.1161/HYPERTENSIONAHA.114.04670.

[21] Tanigaki K, Sacharidou A, Peng J, Chambliss KL, Yuhanna IS, Ghosh D, et al. Hyposialylated IgG activates endothelial IgG receptor FcyRIIB to promote obesityinduced insulin resistance. J Clin Invest 2018;128:309-22. https://doi.org/10.1172/JCl89333.

[22] Peng J, Vongpatanasin W, Sacharidou A, Kifer D, Yuhanna IS, Banerjee S, et al. Supplementation with the Sialic Acid Precursor N-acetyl-D-Mannosamine Breaks the Link Between Obesity and Hypertension. Circulation 2019. https://doi.org/10.1161/circulationaha.119.043490.

[23] Tijardović M, Marijančević D, Bok D, Kifer D, Lauc G, Gornik O, et al. Intense Physical Exercise Induces an Anti-inflammatory Change in IgG N-Glycosylation Profile. Frontiers in Physiology 2019;10:1-10. https://doi.org/10.3389/fphys.2019.01522.

[24] Nguyen NT, Kim E, Vu S, Phelan M. Ten-year Outcomes of a Prospective Randomized Trial of Laparoscopic Gastric Bypass Versus Laparoscopic Gastric Banding. Ann Surg 2018;268:106-13. https://doi.org/10.1097/SLA.0000000000002348.

[25] O'Brien P. Bariatric surgery and type 2 diabetes: a step closer to defining an optimal approach. The Lancet Diabetes \& Endocrinology 2019;7:889-91. https://doi.org/10.1016/S2213-8587(19)30352-3.

[26] Verdi S, Abbasian G, Bowyer RCE, Lachance G, Yarand D, Christofidou P, et al. TwinsUK: The UK Adult Twin Registry Update. Twin Res Hum Genet 2019;22:523-9. https://doi.org/10.1017/thg.2019.65.

[27] Pavić T, Dilber D, Kifer D, Selak N, Keser T, Ljubičić $Đ$, et al. N-glycosylation patterns of plasma proteins and immunoglobulin $\mathrm{G}$ in chronic obstructive pulmonary disease. J Transl Med 2018;16. https://doi.org/10.1186/s12967-018-1695-0.

[28] Leek JT, Johnson WE, Parker HS, Jaffe AE, Storey JD. The sva package for removing batch effects and other unwanted variation in high-throughput experiments. Bioinformatics 2012;28:882-3. https://doi.org/10.1093/bioinformatics/bts034.

[29] R Core Team (2020). R: A language and environment for statistical computing. $R$ Foundation for Statistical Computing, Vienna, Austria. URL https://www.Rproject.org/.n.d.

[30] Clerc F, Reiding KR, Jansen BC, Kammeijer GSM, Bondt A, Wuhrer M. Human plasma protein N-glycosylation. Glycoconj J 2016;33:309-43. https://doi.org/10.1007/s10719015-9626-2. 
medRxiv preprint doi: https://doi.org/10.1101/2020.04.24.20077867; this version posted September 3, 2020. The copyright holder for this preprint (which was not certified by peer review) is the author/funder, who has granted medRxiv a license to display the preprint in

It is made available under a CC-BY-NC-ND 4.0 International license .

[31] Bates D, Mächler M, Bolker B, Walker S. Fitting Linear Mixed-Effects Models Using Ime4. Journal of Statistical Software 2015;67:1-48. https://doi.org/10.18637/jss.v067.i01.

[32] Ruhaak LR, Uh H-W, Beekman M, Koeleman CAM, Hokke CH, Westendorp RGJ, et al. Decreased Levels of Bisecting GIcNAc Glycoforms of IgG Are Associated with Human Longevity. PLOS ONE 2010;5:e12566. https://doi.org/10.1371/journal.pone.0012566.

[33] Pučić $M$, Knežević A, Vidič J, Adamczyk B, Novokmet $M$, Polašek $O$, et al. High Throughput Isolation and Glycosylation Analysis of IgG-Variability and Heritability of the IgG Glycome in Three Isolated Human Populations. Mol Cell Proteomics 2011;10. https://doi.org/10.1074/mcp.M111.010090.

[34] Lemmers RFH, Vilaj M, Urda D, Agakov F, Šimurina M, Klaric L, et al. IgG glycan patterns are associated with type 2 diabetes in independent European populations. Biochim Biophys Acta Gen Subj 2017;1861:2240-9. https://doi.org/10.1016/j.bbagen.2017.06.020.

[35] lida S, Kuni-Kamochi R, Mori K, Misaka H, Inoue M, Okazaki A, et al. Two mechanisms of the enhanced antibody-dependent cellular cytotoxicity (ADCC) efficacy of nonfucosylated therapeutic antibodies in human blood. BMC Cancer 2009;9:58. https://doi.org/10.1186/1471-2407-9-58.

[36] Kaneko Y, Nimmerjahn F, Ravetch JV. Anti-Inflammatory Activity of Immunoglobulin G Resulting from Fc Sialylation. Science 2006;313:670-3. https://doi.org/10.1126/science.1129594.

[37] Sarin HV, Gudelj I, Honkanen J, Ihalainen JK, Vuorela A, Lee JH, et al. Molecular Pathways Mediating Immunosuppression in Response to Prolonged Intensive Physical Training, Low-Energy Availability, and Intensive Weight Loss. Front Immunol 2019;10:907. https://doi.org/10.3389/fimmu.2019.00907. 
medRxiv preprint doi: https://doi.org/10.1101/2020.04.24.20077867; this version posted September 3, 2020. The copyright holder for this preprint (which was not certified by peer review) is the author/funder, who has granted medRxiv a license to display the preprint in It is made available under a CC-BY-NC-ND 4.0 International license.

TABLES

574 Table 1 Demographic characteristics of the bariatric cohort

\begin{tabular}{|c|c|c|c|c|c|}
\hline Characteristics & \multicolumn{5}{|c|}{ Bariatric cohort } \\
\hline $\begin{array}{l}\text { Total No. of participants } \\
\text { (N) }\end{array}$ & \multicolumn{5}{|l|}{37} \\
\hline $\begin{array}{l}\text { No. of participants Sleeve } \\
\text { Gastrectomy (SG), N (\%) }\end{array}$ & \multicolumn{5}{|l|}{$25(68 \%)$} \\
\hline $\begin{array}{l}\text { No. Roux-en-Y Gastric } \\
\text { Bypass RYGB N (\%) }\end{array}$ & \multicolumn{5}{|l|}{$12(32 \%)$} \\
\hline $\begin{array}{l}\text { No. of participants each } \\
\text { timepoint }(\mathrm{N})\end{array}$ & \multicolumn{2}{|c|}{ Pre-op low-calorie diet } & $\begin{array}{l}\text { Time of } \\
\text { surgery }\end{array}$ & $\begin{array}{l}\text { 1st post-op } \\
\text { timepoint }\end{array}$ & $\begin{array}{l}2^{\text {nd }} \text { post-op } \\
\text { timepoint }\end{array}$ \\
\hline & \multicolumn{2}{|l|}{8} & 37 & 30 & 24 \\
\hline \multirow[t]{2}{*}{$\begin{array}{l}\text { BMI* each timepoint, } \\
\text { mean } \pm S D, k g / m 2\end{array}$} & Before diet & End of diet & $\begin{array}{l}\text { Time of } \\
\text { surgery }\end{array}$ & $\begin{array}{l}1^{\text {st }} \text { post-op } \\
\text { timepoint }\end{array}$ & $\begin{array}{l}2^{\text {nd }} \text { post-op } \\
\text { timepoint }\end{array}$ \\
\hline & $48.53 \pm 4.13$ & $46.60 \pm 4.21$ & $46.21 \pm 4.75$ & $36.01 \pm 5.07$ & $32.82 \pm 5.17$ \\
\hline Female, sex, $\mathrm{N}(\%)$ & \multicolumn{5}{|l|}{$33(89 \%)$} \\
\hline Type 2 diabetes, N (\%) & \multicolumn{5}{|l|}{$6(16 \%)$} \\
\hline
\end{tabular}

575

576 *BMI reference values: <18.5 (underweight), 18.5-24.9 (normal weight), 25-29.9

577 (overweight), >30 (obese). 
medRxiv preprint doi: https://doi.org/10.1101/2020.04.24.20077867; this version posted September 3, 2020. The copyright holder for this preprint (which was not certified by peer review) is the author/funder, who has granted medRxiv a license to display the preprint in It is made available under a CC-BY-NC-ND 4.0 International license.

Table 2 Demographic characteristics of the TwinsUK cohort

\begin{tabular}{|l|l|}
\hline Characteristics & TwinsUK cohort (BMI subset) \\
\hline No. of participants (N) & 1,680 \\
\hline No. of glycan measurements (N) & 3,742 \\
\hline Baseline age, mean \pm SD, years & $53.23 \pm 10.86$ \\
\hline Follow up time, mean \pm SD, years & $7.90 \pm 5.66$ \\
\hline Female sex, N (\%) & $1,680(100)$ \\
\hline Baseline BMI, mean \pm SD, kg/m² & $25.45 \pm 4.53$ \\
\hline
\end{tabular}
using Benjamini-Hochberg method at the specified level of 0.05 .

\begin{tabular}{|l|c|c|c|c|}
\hline Derived IgG glycan trait & Time_effect & Time_SE & Time_p-value & Adjusted p-value \\
\hline \hline bisecting GlcNAc (B) & -0.2801 & 0.0743 & 0.0043 & 0.0341 \\
\hline agalactosylation (G0) & -0.0493 & 0.1876 & 0.7930 & 0.7930 \\
\hline monogalactosylation (G1) & 0.1122 & 0.1869 & 0.5526 & 0.7930 \\
\hline digalactosylation (G2) & -0.0539 & 0.1387 & 0.6991 & 0.7930 \\
\hline total sialylation (S) & 0.0941 & 0.2090 & 0.6544 & 0.7930 \\
\hline monosialylation (S1) & 0.1354 & 0.1878 & 0.4779 & 0.7930 \\
\hline disialylation (S2) & -0.0869 & 0.2474 & 0.7266 & 0.7930 \\
\hline core fucosylation (CF) & 0.0810 & 0.2416 & 0.7385 & 0.7930 \\
\hline
\end{tabular}


medRxiv preprint doi: https://doi.org/10.1101/2020.04.24.20077867; this version posted September 3, 2020. The copyright holder for this preprint (which was not certified by peer review) is the author/funder, who has granted medRxiv a license to display the preprint in It is made available under a CC-BY-NC-ND 4.0 International license.

587 Red - significant decrease; blue - non-significant change. GlcNAc - N-acetylglucosamine; SE -

588 standard error

589

590 Table 4 Bariatric surgery induces significant changes in IgG N-glycome. Longitudinal analysis

591 was performed by implementing a linear mixed effects model, with time as a fixed effect and

592 the individual sample measurement as a random effect. False discovery rate was controlled

593 using Benjamini-Hochberg method at the specified level of 0.05 .

\begin{tabular}{|l|r|r|r|r|}
\hline Derived IgG glycan trait & Time_effect & Time_SE & Time_p-value & Adjusted $\boldsymbol{p}$-value \\
\hline \hline agalactosylation (G0) & -0.0339 & 0.0078 & $9.23 \times 10^{-05}$ & $7.38 \times 10^{-04}$ \\
\hline digalactosylation (G2) & 0.0275 & 0.0072 & $3.75 \times 10^{-04}$ & $1.50 \times 10^{-03}$ \\
\hline monosialylation (S1) & 0.0193 & 0.0080 & $1.97 \times 10^{-02}$ & $3.94 \times 10^{-02}$ \\
\hline core fucosylation (CF) & -0.0155 & 0.0064 & $1.74 \times 10^{-02}$ & $3.94 \times 10^{-02}$ \\
\hline total sialylation (S) & 0.0171 & 0.0083 & $4.70 \times 10^{-02}$ & $6.27 \times 10^{-02}$ \\
\hline bisecting GIcNAc (B) & 0.0173 & 0.0083 & $4.01 \times 10^{-02}$ & $6.27 \times 10^{-02}$ \\
\hline monogalactosylation (G1) & 0.0206 & 0.0107 & $8.18 \times 10^{-02}$ & $9.35 \times 10^{-02}$ \\
\hline disialylation (S2) & 0.0048 & 0.0080 & $5.48 \times 10^{-01}$ & $5.48 \times 10^{-01}$ \\
\hline
\end{tabular}

Red - significant decrease; green - significant increase; blue - non-significant change.

595 GlcNAc - N-acetylglucosamine; SE - standard error 
medRxiv preprint doi: https://doi.org/10.1101/2020.04.24.20077867; this version posted September 3, 2020. The copyright holder for this preprint (which was not certified by peer review) is the author/funder, who has granted medRxiv a license to display the preprint in It is made available under a CC-BY-NC-ND 4.0 International license.

604 Table 5 Longitudinally monitored weight loss results with significant changes of IgG N-

605 glycosylation. Longitudinal analysis was performed by implementing a mixed model, fitted

606 to estimate the effect of BMI change on IgG N-glycome. False discovery rate was controlled

607 using Benjamini-Hochberg method at the specified level of 0.05.

\begin{tabular}{|c|c|c|c|c|}
\hline Derived IgG glycan trait & $\begin{array}{l}\text { BMI difference effect (glycan } \\
\text { abundance (\%) change per } \\
1 \mathrm{kgm}^{-2} \text { decrease in BMI) }\end{array}$ & $\begin{array}{l}\text { BMI difference SE (glycan } \\
\text { abundance (\%) change per } \\
1 \mathrm{kgm}^{-2} \text { decrease in BMI) }\end{array}$ & p-value & $\begin{array}{c}\text { Adjusted } \\
p \text {-value }\end{array}$ \\
\hline digalactosylation (G2) & 0.2004 & 0.0403 & $6.88 \times 10^{-07}$ & $5.85 \times 10^{-06}$ \\
\hline high mannose (HM) & -0.0519 & 0.0119 & $1.33 \times 10^{-05}$ & $5.66 \times 10^{-05}$ \\
\hline agalactosylation (G0) & -0.1048 & 0.0397 & $8.43 \times 10^{-03}$ & $1.79 \times 10^{-02}$ \\
\hline bisecting GIcNAc (B) & 0.0526 & 0.0262 & $4.49 \times 10^{-02}$ & $6.94 \times 10^{-02}$ \\
\hline monogalactosylation (G1) & -0.0573 & 0.0343 & $9.53 \times 10^{-02}$ & $1.25 \times 10^{-01}$ \\
\hline core fucosylation (CF) & -0.0059 & 0.0285 & $8.36 \times 10^{-01}$ & $8.89 \times 10^{-01}$ \\
\hline
\end{tabular}

608 Red - significant decrease; green - significant increase; blue - non-significant change.

609 GlcNAc - N-acetylglucosamine; SE - standard error 